\title{
Ulupamir-Kırgız Adlarındaki Ad Seçimi Farklılaşmaları (Ulupamir Mahallesi Örneği)*
}

\author{
Rabia Şenay ŞişMAN**
}

Öz

Hızla gerçekleşen sosyal değişim ve gelişim karşısında ad verme geleneğinin idrak ettiği farklılaşmaları, kişi adları üzerinden takip etme gereği düşünülmüş ve Anadolu Türkçesiyle Ulupamir halkının bağlı olduğu Orta Asya Türk dilinin karşılıklı etkileşimleri sonrası yerel sözcüklerin içinde bulunduğu hâl ve anlam bilgisine ulaşma ihtiyacı doğrultusunda bir çalışma planlanmış; ses-anlam ile ilintili değişikliklerin yerinde tespiti için saha kaynaklı veriler öncelikli kılınmıştır.

Ulupamir Kırgız Türkleri çerçevesinde planlanmış incelemenin amacı 1995-2015 yılları arasındaki topluluk kişi adları seçiminde âmil olan unsurları belirlemek şeklindedir. Düşünülen unsur tespiti işlevinin yanında kişi adlarında anlamdan bağımsız görülen düzensiz ses olaylarıyla ilgili bazı özellikler saptanmıştır. Bu saptamalara ait elde edilmiş bulgular çalışmanın alt basamaklarını oluşturacak bir düzenlemeyle ifade edilmiştir.

Adlandırma geleneği üzerine kurulu bu araştırmada, alışkanlıklar kişi adı boyutunda ele alınmış ve dün ile bugünün farkını ortaya koymak amacıyla çalışma yapılandırılmıştır. Bulguların dille ilişkili disiplinlere olumlu veri katkısı sunacağı umulmaktadır.

Anahtar Kelimeler: Ulupamir Mahallesi-Kırgız Türkleri, dil bilimi, kişi adı.

\footnotetext{
* Bu Çalışma, Muş Alparslan Üniversitesi Bilimsel Araştırma Projeleri Koordinasyon Birimince Desteklenmiştir. Proje Numarasi: BAP- MŞÜ16-EMF-G03/2018

** Dr. Öğretim Üyesi. Rabia Şenay Şişman, Muş Alparslan Üniversitesi, Eğitim Fakültesi, Türkçe Eğitimi Bölümü, Türkiye.

Elmek: rs.sisman@alparslan.edu.tr
} 


\title{
Name Choic e Differences In Ulupamır Kyrgyz Names \\ (Ulupamir Neighborhood Example)
}

\begin{abstract}
It is important to follow the traces of change in the naming traditions through person names in the face of social change and development and it is also important to keep the records of the meanings of the names. In this respect, we attempted to design a research to have the knowledge of sound and meaning of the local words after the mutual effects of Anatolian Turkish and the Central Asian Turkic language, with which the people of Ulupamir have ties, to each other.

The main concerns of the study are: to determine the principal factors of the proper noun choices among Kyrgyz Turks between the years of 1995-2015, sharing the findings about the irregular phonological changes that are independent from the meanings. The findings that are obtained from the study are expressed in a way that they form the sub steps of the study.

In this research the traditions are taken into consideration on the level of person names and it formed in order to show the differences between past and present. There is also no doubt that this research will have positive contributions to the disciplines that are related to linguistics.
\end{abstract}

Keywords: Ulupamir Neighborhood- Kyrgyz Turks, linguistics, person name. 


\section{Giriş}

"Dil insan, toplum, insan ve toplumdan ayrı düşünülemeyecek olan bilim, sanat, teknik gibi bütün alanlarla ilgili, aynı zamanda onları oluşturan bir kurumdur". (Aksan, 1987) Çeşitli disiplinlerce incelemeye açık olan dil müessesesinin gelişimi ses, biçim, anlam, söz dizimi gibi dil alanları üzerinden takip edilebilir. Bunlardan biri ad bilimi şeklinde nitelendirilen dil bilimi alanıdır ve canlıların, nesnelerin, kavramların bir diğer ifadeyle çevremizde algıladığımız her tür şeyin adıyla ilgilenen bilimdir (Sakaoğlu, 2001: 9). ${ }^{1}$

Kişi adları bilimi yani antroponomi (anthroponymy), bu bilim dalını içine alan özel ad biliminin (onomastique) çalışma alanlarındandır. (Aksan, 1995) Takma adlar, göbek adı, soyadı ve hatta unvanlar kişi adları bilimi içerisinde değerlendirilmektedir. Acıpayamlı'ya göre ad vermede kullanılan kişi adları "basit bir ad verme olgusu durumundan çıkarak, her topluluk ve toplumun yapı ve anlayışına uygun bir şekilde çok aşamalı; her aşaması sayısız gelenek, görenek ve uygulamalardan oluşan dev bir 'folklor olayı' durumuna dönüşmüştür’. (Acıpayaml1, 1992) Gülensoy'a göre kişi adları bir milletin dil, folklor, tarih ve kültürü açısından büyük önem taşır. (1999: 3-8) Bu anlamda ad verme ve ad kaynakları barındırdığı birikim çeşitliliğiyle ilişkili olarak çok disiplinli araştırmaların incelemelerine açıktır.

Adlar, ön kabulle oluşmuş yaklaşımların tercih edilmiş sözcükleridir. Yüzyılların damıttığı türlü sesler toplumsal eğilimlerin karekteristik özellikleriyle harmanlanmış, çoğu zaman geleneksel çerçevenin izin verdiği bir ses-anlam yapısıyla, varlıklara ad olmuştur. Bireyi sosyal ve kültürel alışverişlerinde tanımlayan simge şeklinde nitelendirebileceğimiz kişi adları, bünyesindeki ses oluşumları yanı sıra, ardındaki medeniyet düşüncesinin alfabetik kodu olma özelliği ile âdeta toplumun yapısal nüvesidir. Mesela "İslam kültüründe son derece normal bir isim olan Hacı Ali isminin, 19. yüzyıl Amerika'sında insanları gülümseten 'Hi July' haline gelmesi Amerika'nın kültürel algılama biçimleri hakkında bize önemli ipuçları vermektedir. Burada bir kabul ve red vardır. Bir Osmanlı vatandaşının 
Müslüman kimliğini muhafaza ederek Amerika'da kalması, aile kurması, müslüman olarak ölmesi şeklinde tezahür eden silsile kabuldür; isminin 'Hi July' haline gelmesi ise İslam ve Amerikan kültürlerinin beklenmedik tedahülüne örnek teşkil edecek niteliktedir". (Kalın, 2016: 331)

Türklerin ad verme ile ilgili ritüelleri ana yurtta tarih sahnesine çıtıkları devre dek uzanan bir geçmişi ve bu geçmiş ile ilintili birikimleri barındırır. Tasarruf edilmiş hayvan adları, tabiat kaynaklı adlandırmalar, kavmî-târihî adlar hep bu dönemin yaşam alışkanlıklarını, din görüşünü ve kültür birikimini yansıtır. Dünyayı algılayış biçimi ile dil arasındaki kurulu bağın adlara ilişkin takibinde, baskın eğilimlerin belirlenmesi için söz konusu bu birikimden hareketle, günümüze ait izdüşümleri belirlemek mümkündür.

\section{Türklerde Adlandırmalara Özgü Temayüllerin Başlıcaları Şöyle Siralanabilir}

Tabiat ile barışık göçebe bir toplum geçmişi olan Türklerin gök cisimleri ile doğa olaylarından esinlenmeleri ya da maden, bitki ile hayvanlardan hatta çeşitli alet isimlerinden etkilenerek ad koymaları malumdur. Nitekim Oğuznâme'de Kağan Oğuz, çocuklarına Gün, Ay, Yulduz (Yıldız) gibi isimler vermiştir. İslamiyetin kabulünden sonra Yusuf Has Hacib'in kaleme aldığı mühim eser Kutadgu Bilig'de geçen Ay Toldı ve Kün Togdı gibi yine tabiata özgü olan Türkçe isimler bu türden somut kaynaklı adlar sınıfindandır.

Hürmet edilen büyüklerin adını vermek, bebeği korumaya yönelik ad koymalar, temenni ve benzeri amaçlı adlandırmalar, hepsi birden ebeveynin evrensel nitelikli niyet, arzu, hayal ve özlemlerinin karşıllğı olan iyi ve güzel anlamlı kullanımlar olarak yorumlanmıştır. Mesela, "Ağır geldi” diye çocuğun adını değiştirmek, çok yaşayan ya da güzel yaşayan kişilerin adını tercih etmek ya da kötü ruhları bebekten uzaklaştırma amacıyla "çirkin" diye seslenişleri âdet hâline getirmek, hep bebeği koruma, onun güzel bir ömür sürmesini umma amaçlarına dönük eğilimlerdir. Ebeveynin bu nevi beklenti ve dilekleri yanında yeni doğan bebeğin görünümü; doğum anı ya da doğum sonrası karşılaşılan çarpıcı bir durum gibi anlık detaylara ilişkin adlandırmalar da vardır.

Ata erkil toplum düzeninin bir icabı olarak erkek ile kız evlat isimlendirmelerinde farklılık vardır. Kız çocukları için tasarlanan adlarda güzellik, çekicilik, alımlılık ve değerliliğin ön planda tutulması, erkek çocuk için seçilenlerde kuv- 
vet, cesaret, ihtişam, yeterlilik gibi anlamların aranması, bu sosyal yaklaşımının sebep olduğu sonuçlardır.

Anlam kötüleşmesi ya da anlam iyileşmesi gibi anlama yönelik değişimler, kişi adları için de geçerlidir. Mesela Yosma "Güzel, çok güzel" anlamında iken günümüzde "1. Edâlı, işveli, oynak kadın. 2. Süslü ve modaya düşün kadın, koket (Ayverdi, 2015: 3440) anlamlarıyla farklı algılar uyandırdığından artık kişi adı olarak kullanımdan düşmüştür. Yine mecazen "bir türbeye, bir ulu zâta veya Allah'a adanmış kimse" (Ayverdi 2015: 2685) anlamına gelen ya da erkek çocukları çok ölen aileler tarafindan 'kötü ruhlar'ın çocukları almasına engel olmaya yönelik Şamanist bir inancın kalıntısı olduğu öne sürülen Satılmış ismi de aynı şekilde anlam kötüleşmesinden dolayı artık pek rağbet edilir türden değildir.

Kişi adları bireysel ve toplumsal kimlik edinilmesinde etken bir faktördür. Çünkü kişi adları, bireyin sosyalleşme cephesini güçlü kılarken, kamusal aidiyet hissinin devamlılığını sağlayan ilişkilerin başlatıcısıdır. Bu anlamda sosyal hayattaki tutum ve tavırların biçimlendiricisidir.

Kişi adı tercihleri, toplum ve bireyin sosyal ve kültürel gelişim ve değişimlerin tespit edilebildiği sosyal bir yansıdır. Çünkü "kişi adları dil sosyolojisi açısından incelendiğinde bir toplumda veya grupta sosyo-kültürel süreç ve yap1ların anlaşılmasına yardımcı olur". (Çelik, 2005) Tarihsel süreç içinde yapılacak derleme çalışmaları ile toplumların kişi adı tercihlerine tesir eden yaklaşımlarını ortaya çıkarma ve kültür tarihinde çeşitlilik arz eden temayüllerin baskın yönlerini saptamak mümkündür. Çalışmada varılmak istenilen, adı geçen topluluğun kişi adı tercihlerini kriter alarak çoklu disiplinlerin türlü amaçlarına malzeme kazandıracak verileri dil bilimi kesişiminde sunabilmektir.

Anadolu topraklarına yerleşmiş Kırgız toplumunun isim-kültür formunun incelendiği bu çalışmada geleneksel anlayışın göç ekseninde uğradığı varsayılan kültürel erozyon yanında küreselleşme, sanayileşme, kentleşme gibi faktörlerin biçimlendirmeye dayalı sosyal baskı düzeyleri ad verme alışkanlıkları üzerinden belirlenmeye çalışılmıştır.

\section{Amaç}

Çalışmanın amacı Van Erciş nüfusuna kayıtlı Ulupamir Mahallesi halkında tasarruf edilen kişi adlarını belirlemek, son yirmi yılın kişi adlandırılmalarında 
varsa değişen tutumları gösterebilmek ve tespit edilen farklılaşmalar üzerinden, kişi adlarında egemen eğilimlere işaret edebilmektir. Bu araştırma, ad taraması ve anket sonrası elde edilen doküman üzerinden dile dönük incelemeler yoluyla aşamalandırılmıştır.

\section{Yöntem}

Anket ve görüşme modeline dayalı ve ağırlıklı olarak betimsel bir çalışma ile yapılan incelemenin birinci aşamasında, araştırma sonuçlarını genellemek istediğimiz bütün demek olan belli bir evrenden yani dar anlamda evrenimiz Ulupamir (1054 kişilik) halkı üzerinden, rastlantısal seçme metodu kullanılarak örneklem grubu oluşturulmuştur.

Örneklem grubunu bariz kılmak adına göç ve Ulupamir'de bulunma süreleriyle ilgili bilgilerin edinildiği sorulara öncelik tanınmış; grubun taşıdığ 1 ve beğendiği kişi adlarıyla ilgili belirlemelerin yapıldığı sorulara verilen cevaplarla şekillenmiş bulgular konunun sınırları dâhilinde değerlendirilmeye çalışılmıştır.

\section{Evren}

Çalışma kapsamındaki Ulupamir'de ikamet eden Kırgızlar'ın 2015 verilerine göre nüfusu TUİK Adrese Dayalı Nüfus Kayıt Sistemine göre 785 Erkek; 749 Kadın olmak üzere toplam 1534 kişidir ve bu çerçeve içinden \% 7'lik paya denk düşen kişi rastlantısal metotla örneklem grubu olarak belirlenmiştir. 288 hane sayısına sahip olan nüfusun yaş gruplarına göre dağılımında çocuk ve gençlerin (05-19 yaş grubu) yoğunluğunun görüldüğü veriler şu şekildedir:

01-04 yaş grubu arası 121 kişi; 05-09 yaş grubu arası 137 kişi; 10-14 yaş grubu arası 177 kişi; 15-19 yaş grubu arası 197 kişi; 20-24 yaş grubu arası 140 kişi; 25-29 yaş grubu arası 140 kişi; 30-34 yaş grubu arası 116 kişi; 35-39 yaş grubu arası 64 kişi; 40-44 yaş grubu arası 89 kişi; 45-49 yaş grubu arası 75 kişi; 50-54 yaş grubu arası 66 kişi; 55-59 yaş grubu arası 73 kişi; 60-64 yaş grubu arası 62 kişi; 65 ve üstü yaş grubu arası 123 kişi

Kaynakça: TUIK (2015)

Son yirmi yıl içinde Ulupamir kişi adlarındaki değişim temayülünün ele alındığı bu çalışma, Kırgız Türk dilinin güneybatı ağzı grubuna dâhil olan İçkilik ağzı özelliklerini taşıyan Ulupamir Kırgızlarıyla ilgilidir. Van-Erçiş ilçesine 32 
km uzaklıkta kurulu bu mahallenin sakinleri bulundukları coğrafyaya ait dili de işlek kullanmaları sebebiyle bir diğer ifadeyle Türkiye Türkçesiyle olan sıkı etkileşimleri sonrası kullanılan Ulupamir ağzıyla, standart İçkilik ağzı arasında bazı ses ayrımları gerçekleşmiş olabilir. Bu düşünceden hareketle kişi adı seçiminin değiş̧imiyle ilişkili tespitler yapılırken adlarda görülen bazı ses özelliklerini de belirleme yoluna gidilmiştir.

Kırgız isimlerinin yapı ve anlam bakımından analizi için Clauson Etimolojik Sözlüğü ile Türk Dil Kurumu; Kişi Adları, Derleme ve Kırgız Sözlüklerine ve Türkçenin Grameri (Banguoğlu, 1974) ile Pamir Ağzı üzerine yapılmış bir tez çalışmasının sözlük kısmına (Pekacar, 1995) başvurulmuştur. Adı geçen kaynaklarla beraber, üniversite öğrencisi üç bayan ${ }^{2}$, iki lise son sınıf öğrencisi genç kız ve iki orta yaş ile bir tane orta yaş üstü ev hanımından oluşmuş kılavuz kimselerin yardım ve anlatımları, çalışmanın şekillenmesinde etkili olmuştur.

\section{İnceleme}

Mahalle halkı şeklindeki evren çerçevesinden rastlantısal olarak seçilen örneklem grubunun adları ve bu grubun verdiği cevaplar doğrultusunda oluşmuş, taşıdıkları adların ne şekilde koyulduğu ve anlamın ne olduğu bilgisinin sorgulanmasıyla ilgili verilen cevaplarla düzenlenmiş belirlemelerde ön adlar, önce anlam temelinde ele alınmış; ad vermede baskın etmenler "tercih sebebi" başlığ 1 altında örneklem grubunun cevaplarının çizdiği sınırlamalarla tasnif edilmiştir.

İncelemelerden ulaşılan sonuçlar değerlendirilerek, Ulupamir mahallesi kişi adı tercihleri, günümüz yaklaşımlarıyla yansıtılmaya çalışılmıştır.

\section{Bulgular ve Yorumlar}

Örneklem grubunun \%47'lik pay ile yarıya yakın kısmı Ulupamir'de doğan kimselerden oluşmaktadır.

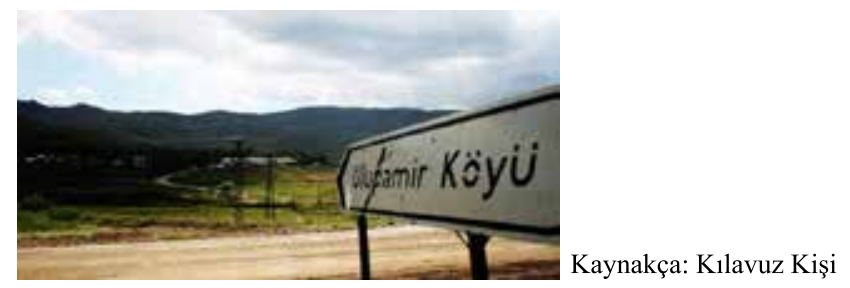

2 Sağlık Yüksek Okulu, Fen Edebiyat Fakültesi Türk Dili ve Edebiyatı Bölümü ile Sosyoloji Bölümü öğrencileri. 
Pamir halkı arasından seçilmiş örneklem grubunun mensup olduğu ailelerin kaç yıldır aynı köyde/mahallede ikamet ediyor olmasının yüzdelik oranları 35 yıldır yaşayan $\% 34,6 ; 36$ yıldır yaşayan $\% 3,8 ; 42$ yıldır yaşayan $\% 1$ şeklindedir.

Tablo 1: Örneklem Grubunun Ulupamir Mahallesinde Bulunma Süreleriyle İlgili Tablolar

\begin{tabular}{|c|c|c|c|c|}
\hline $\begin{array}{c}\text { Kaç yıldır } \\
\text { Ulupamir'de } \\
\text { oturuyorsunuz? }\end{array}$ & Sıklık Miktarı & Yüzde & Geçerli Yüzde & $\begin{array}{l}\text { Yoğunluklu } \\
\text { Yüzde }\end{array}$ \\
\hline 7,00 & 2 & 1,9 & 1,9 & 1,9 \\
\hline 8,00 & 1 & 1,0 & 1,0 & 2,9 \\
\hline 9,00 & 1 & 1,0 & 1,0 & 3,8 \\
\hline 10,00 & 2 & 1,9 & 1,9 & 5,8 \\
\hline 12,00 & 2 & 1,9 & 1,9 & 7,7 \\
\hline 13,00 & 1 & 1,0 & 1,0 & 8,7 \\
\hline 14,00 & 2 & 1,9 & 1,9 & 10,6 \\
\hline 15,00 & 2 & 1,9 & 1,9 & 12,5 \\
\hline 16,00 & 5 & 4,8 & 4,8 & 17,3 \\
\hline 17,00 & 3 & 2,9 & 2,9 & 20,2 \\
\hline 18,00 & 1 & 1,0 & 1,0 & 21,2 \\
\hline 20,00 & 2 & 1,9 & 1,9 & 23,1 \\
\hline 21,00 & 2 & 1,9 & 1,9 & 25,0 \\
\hline 22,00 & 4 & 3,8 & 3,8 & 28,8 \\
\hline 23,00 & 2 & 1,9 & 1,9 & 30,8 \\
\hline 24,00 & 1 & 1,0 & 1,0 & 31,7 \\
\hline 25,00 & 2 & 1,9 & 1,9 & 33,7 \\
\hline 26,00 & 1 & 1,0 & 1,0 & 34,6 \\
\hline 27,00 & 2 & 1,9 & 1,9 & 36,5 \\
\hline 28,00 & 1 & 1,0 & 1,0 & 37,5 \\
\hline 29,00 & 4 & 3,8 & 3,8 & 41,3 \\
\hline 30,00 & 10 & 9,6 & 9,6 & 51,0 \\
\hline 31,00 & 1 & 1,0 & 1,0 & 51,9 \\
\hline 32,00 & 3 & 2,9 & 2,9 & 54,8 \\
\hline 33,00 & 4 & 3,8 & 3,8 & 58,7 \\
\hline 34,00 & 2 & 1,9 & 1,9 & 60,6 \\
\hline 35,00 & 36 & 34,6 & 34,6 & 95,2 \\
\hline 36,00 & 4 & 3,8 & 3,8 & 99,0 \\
\hline 42,00 & 1 & 1,0 & 1,0 & 100,0 \\
\hline Toplam & 104 & 100,0 & 100,0 & \\
\hline
\end{tabular}


Ulupamirli Kırgız gençleri, eğitim seviyeleri yükseldikçe; büyük şehirlere iş bulma amacıyla gidip o diyarların hayat şartlarına alışmalarıyla ve bunun yanı sıra yaşlı nüfusun ölüm gibi olası sebeplerle toplum hayatındaki etki güçlerinin zamanla zayıflaması süreci sonrası, geleneklerin denetiminden kısmen de olsa uzaklaşmaktadırlar. Ama yine de, değişimin zorlayıcılığına dirençli bir tutumla karşı durarak, kültürlerini yaşatmaya kararlı olan büyüklerinin peşinden gitmeyi bir vefa borcu gibi görmekten de vazgeçmiyorlar. Kişi adlarının önüne ya da arkasına (Bibicemal, Ziyadahan vb.) eklenmesiyle elde edilen Türkçe köklü unvan adları ya da Türkçe sözcüklerle kurulan sıfat (Aksenam, Tatlı̈ülü) ve isim tamlamaları (Cihanbay, Cihanbek "cihanın zengini, cihanın beyi”) şeklinde gerçekleşmiş adlandırmalarda olduğu gibi Arapça ya da Farsça benzeri farklı dil köklerine sahip kişi adlarını Türkçe sözcük ya da eklerle yeni baştan düzenlemeleri bu tutumun bir delili olarak yorumlanabilir.

Tablo 2: Örneklem Grubunun İsim Sorgusu Tablosu

\begin{tabular}{|r|r|r|r|r|}
\hline & \multicolumn{5}{|c|}{ İsminiz Nedir? } & \\
\hline ABDULAZIZ & 1 & 1,0 & 1,0 & 1,0 \\
\hline ABDULBAKİ & 1 & 1,0 & 1,0 & 1,9 \\
\hline ABDULKAMÇI & 1 & 1,0 & 1,0 & 2,9 \\
\hline AÇELYA & 1 & 1,0 & 1,0 & 3,8 \\
\hline AKULAK & 1 & 1,0 & 1,0 & 4,8 \\
\hline ALTIMIŞ & 1 & 1,0 & 1,0 & 5,8 \\
\hline ALTINAY & 1 & 1,0 & 1,0 & 6,7 \\
\hline ARAPBAY & 1 & 1,0 & 1,0 & 7,7 \\
\hline ASTANAVEK & 1 & 1,0 & 1,0 & 8,7 \\
\hline AYNUR & 1 & 1,0 & 1,0 & 9,6 \\
\hline AYSEL & 2 & 1,9 & 1,9 & 11,5 \\
\hline AYŞE & 2 & 1,9 & 1,9 & 13,5 \\
\hline AZIZULLAH & 1 & 1,0 & 1,0 & 14,4 \\
\hline BARDİBEK & 1 & 1,0 & 1,0 & 15,4 \\
\hline BARIŞ & 1 & 1,0 & 1,0 & 16,3 \\
\hline BAYRAM & 1 & 1,0 & 1,0 & 17,3 \\
\hline BAZARHAN & 1 & 1,0 & 1,0 & 18,3 \\
\hline BEGDİ & 1 & 1,0 & 1,0 & 19,2 \\
\hline BEKİ & 1 & 1,0 & 1,0 & 20,2 \\
\hline & & & &
\end{tabular}


Rabia Şenay ŞİSMAN, Ulupamir-Kırgız Adlarındaki Ad Seçimi Farklılaştırmaları (Ulupamir Mahallesi Örneği)

\begin{tabular}{|c|c|c|c|c|}
\hline BİLAL & 1 & 1,0 & 1,0 & 21,2 \\
\hline BİLGE & 1 & 1,0 & 1,0 & 22,1 \\
\hline BUKET & 1 & 1,0 & 1,0 & 23,1 \\
\hline CABBAR & 1 & 1,0 & 1,0 & 24,0 \\
\hline CANAN & 1 & 1,0 & 1,0 & 25,0 \\
\hline CAVIDAN & 1 & 1,0 & 1,0 & 26,0 \\
\hline CENGIZ & 1 & 1,0 & 1,0 & 26,9 \\
\hline ÇEÇE & 1 & 1,0 & 1,0 & 27,9 \\
\hline EDA & 1 & 1,0 & 1,0 & 28,8 \\
\hline EMRAH & 1 & 1,0 & 1,0 & 29,8 \\
\hline ERKEHAN & 1 & 1,0 & 1,0 & 30,8 \\
\hline GÜL & 1 & 1,0 & 1,0 & 31,7 \\
\hline GÜLBİBİ & 1 & 1,0 & 1,0 & 32,7 \\
\hline GÜLDENIZ & 1 & 1,0 & 1,0 & 33,7 \\
\hline GÜLDERHAN & 1 & 1,0 & 1,0 & 34,6 \\
\hline GÜLNUR & 1 & 1,0 & 1,0 & 35,6 \\
\hline GÜRPE & 1 & 1,0 & 1,0 & 36,5 \\
\hline HACER & 2 & 1,9 & 1,9 & 38,5 \\
\hline HATICE & 2 & 1,9 & 1,9 & 40,4 \\
\hline HOŞVAKİT & 1 & 1,0 & 1,0 & 41,3 \\
\hline HURIYYE & 1 & 1,0 & 1,0 & 42,3 \\
\hline HÜLYA & 1 & 1,0 & 1,0 & 43,3 \\
\hline IRIZ & 1 & 1,0 & 1,0 & 44,2 \\
\hline ISABEK & 1 & 1,0 & 1,0 & 45,2 \\
\hline İDRİ & 1 & 1,0 & 1,0 & 46,2 \\
\hline İSLAM & 1 & 1,0 & 1,0 & 47,1 \\
\hline İSMAİL & 1 & 1,0 & 1,0 & 48,1 \\
\hline KADIR & 1 & 1,0 & 1,0 & 49,0 \\
\hline KALDIĞAÇ & 1 & 1,0 & 1,0 & 50,0 \\
\hline KANT & 1 & 1,0 & 1,0 & 51,0 \\
\hline KAVUL & 1 & 1,0 & 1,0 & 51,9 \\
\hline KULEK & 1 & 1,0 & 1,0 & 52,9 \\
\hline LALE & 1 & 1,0 & 1,0 & 53,8 \\
\hline MARCAK & 1 & 1,0 & 1,0 & 54,8 \\
\hline MEHMET & 1 & 1,0 & 1,0 & 55,8 \\
\hline MERYEM & 1 & 1,0 & 1,0 & 56,7 \\
\hline MUHAMMED & 2 & 1,9 & 1,9 & 58,7 \\
\hline MUSA & 1 & 1,0 & 1,0 & 59,6 \\
\hline NAZIM & 1 & 1,0 & 1,0 & 60,6 \\
\hline
\end{tabular}




\begin{tabular}{|c|c|c|c|c|}
\hline NECMETTIN & 1 & 1,0 & 1,0 & 61,5 \\
\hline NESLIHAN & 1 & 1,0 & 1,0 & 62,5 \\
\hline NEVIN & 1 & 1,0 & 1,0 & 63,5 \\
\hline NUREMIN & 1 & 1,0 & 1,0 & 64,4 \\
\hline NURMEMET & 1 & 1,0 & 1,0 & 65,4 \\
\hline NURTEN & 1 & 1,0 & 1,0 & 66,3 \\
\hline NUTKU & 1 & 1,0 & 1,0 & 67,3 \\
\hline OROZBİBİ & 1 & 1,0 & 1,0 & 68,3 \\
\hline ORUÇ & 1 & 1,0 & 1,0 & 69,2 \\
\hline RAMAZAN & 1 & 1,0 & 1,0 & 70,2 \\
\hline RESUL & 1 & 1,0 & 1,0 & 71,2 \\
\hline SAİM & 1 & 1,0 & 1,0 & 72,1 \\
\hline SALI & 1 & 1,0 & 1,0 & 73,1 \\
\hline SEDEF & 1 & 1,0 & 1,0 & 74,0 \\
\hline SEHER & 1 & 1,0 & 1,0 & 75,0 \\
\hline SENA & 1 & 1,0 & 1,0 & 76,0 \\
\hline SEVGİ & 1 & 1,0 & 1,0 & 76,9 \\
\hline SEYIT & 1 & 1,0 & 1,0 & 77,9 \\
\hline SEYREHAN & 1 & 1,0 & 1,0 & 78,8 \\
\hline SOMORHAN & 1 & 1,0 & 1,0 & 79,8 \\
\hline SONGÜL & 1 & 1,0 & 1,0 & 80,8 \\
\hline ŞAKİR & 1 & 1,0 & 1,0 & 81,7 \\
\hline ŞANAY/ŞANOY & 1 & 1,0 & 1,0 & 82,7 \\
\hline ŞERAFETTIN & 1 & 1,0 & 1,0 & 83,7 \\
\hline ŞERBEN/ŞERVEN & 1 & 1,0 & 1,0 & 84,6 \\
\hline ŞÜKRÜ & 1 & 1,0 & 1,0 & 85,6 \\
\hline TORGOY & 1 & 1,0 & 1,0 & 86,5 \\
\hline TURAN & 1 & 1,0 & 1,0 & 87,5 \\
\hline TURGANBÜ & 1 & 1,0 & 1,0 & 88,5 \\
\hline UMUT & 1 & 1,0 & 1,0 & 89,4 \\
\hline UNSUN & 1 & 1,0 & 1,0 & 90,4 \\
\hline YAREN & 1 & 1,0 & 1,0 & 91,3 \\
\hline YASEMIN & 1 & 1,0 & 1,0 & 92,3 \\
\hline YILDIZ & 1 & 1,0 & 1,0 & 93,3 \\
\hline YUSUF & 1 & 1,0 & 1,0 & 94,2 \\
\hline ZAYIVERDİ & 1 & 1,0 & 1,0 & 95,2 \\
\hline ZERRIN & 1 & 1,0 & 1,0 & 96,2 \\
\hline ZIVAYDE & 1 & 1,0 & 1,0 & 97,1 \\
\hline ZUPUN & 1 & 1,0 & 1,0 & 98,1 \\
\hline
\end{tabular}




\begin{tabular}{|r|r|r|r|r|}
\hline ZUNUN & 1 & 1,0 & 1,0 & 99,0 \\
\hline ZULG்ADA & 1 & 1,0 & 1,0 & 100,0 \\
\hline Toplam & 104 & 100,0 & 100,0 & \\
\hline
\end{tabular}

\section{Ad Seçimi, Ad Verme Hakkı ve Usûlü}

Yoğunlaştırılmış yüzdelik dilimlere bakıldığında tanıdık tavsiyesi seçimi \%75 iken diğer seçenek olan aile büyüklerinin isimleri seçimi \% 92.3'lük bir orana çıkmaktadır. Bu itibarla dünden bugüne Ulupamir'de ad koyma öncelikle ata hakkıdır denilebilir.

Adlar her toplumun kendi gelenek ve inancına göre şekillenmekte ya da dönüşüm geçirmektedir. Ulupamir halkınca ad verme için tatbik edilen hususî bir töre ya da tören bulunmamaktadır. Yalnız aile büyüğü doğumdan on beş gün sonra kutlu olduğu düşünüldüğü bir zamanda mesela Cuma günü ve Cuma saati gibi bir vakitte temizlenir ve namaz abdesti alır; bebeğin sağ kulağına ezan okuyarak üç kere adını kulağına fisıldar ve "-mübarek olsun" diyerek iyi hâl dileklerinde bulunur. Kazak Türkleri de on beş gün sonra çocuklarına ad verir. (Ülkütaşır,1938: 194-196)

Din etkisi, müslüman halkların dilinde, inancın sebep olduğu yakınlaşmanın yanı sıra Arap ve Fars kavimlerinin dillerinden kültürel-sosyal-ticaret gibi alanlarda gerçekleştirilen türlü alışverişler sonrası geçen kelime ve terimlerin varlığı olarak da düşünülür. İlerleyen zamanlarda bu kelimelerin kullanım sıklığ1, yabancı dilden gelme algısının unutulduğu bir boyuta ulaşmış ve bu sıklık beraberinde ses ile şekil dönüşümünü de doğal kılmıştır.

İslami değerlerle tanışıklığın kutsal sözler ve metinlerle pekiştirildiği bir kültür ortamında dinî adlandırmalar olgusunun, uyulması gerekli hak ve görevler kapsamında algılanması Arapça köklü adların sık kullanım alışkanlığını oluşturmuştur. Grubun isim konuluş sebepleri arasında belirttikleri Anlamı güzel olduğu için (\%21) ve Aile büyüklerinin isimleri (\%18), Din kaynaklı (\%16) ve Hoşa giden (\%11) olarak ifade ettikleri cevaplarda dinî kaynaklı ad verme cevabının sahip olduğu yüzdelik dilim payı orta düzeydedir. Ad koyma geleneğindeki bu durumun, Kırgız adlarının kullanım sıklık düzeyini azaltmış olması muhtemeldir. 


\section{Tercih Sebeplerince Ulupamir Kişi Adları Sıralaması}

Kırgız Türklerine ait olduğu bilinen Manas Destanı ad koyma âdetinin toplum hayatındaki önemini bildiren bilgiler içermektedir. Burada ad koymanın Oğuz Kağan Destanı'nda veya Dede Korkut Hikâyeleri'ndeki gibi bir merasim ile gerçekleştiği görülür. Aradaki tek fark "bir çocuk baş kesmese, kan dökmese ad komazlar" cümlesinden anlaşılacağı üzere ad koymak için Oğuz Kağan Destanı ve Dede Korkut Hikâyeleri'nde bir kahramanlık gösterilmesi gerekirken, Manas Destanı'nda böyle bir beklentinin olmamasıdır. Manas Destanı'nda doğan çocuğun adı için genellikle toplumdaki büyüklere danışılmakta; bebek, Manas gibi bir destan kahramanı ise ad koyma peygamber gibi ulu kişilerce yapılmakta ya da bu görev Ay Koca ve Hızır gibi kahramanlara düşmektedir. (Yıldız, 1994) Yine Manas Destanı'nda doğarken elinde kül tutarak doğan çocuğu Kül-Çora ve doğarken elinde kan tutan çocuğa da Kan-Çora adının verildiği belirtilmektedir. (Ögel, 2003: 500)

Bu çalışmada tercih sebebi sıralaması yapılırken, Türk kişi adlarının tarihî gelişimini inceleyenler arasında bulunan Gülensoy’un (1999: 3-8) güçlü, güzel görünüşlü hayvan; şehir, ülke ve kavim adları; nehir, göl ve deniz adlarl; renk, yön, bitki, değerli maden, gök cisimleri adları şeklinde özetlenebilecek yaklaş1mı kısmen örnek alınmış bununla beraber örneklem grubuna yöneltilen "ismin konuluş sebebi”ne verilen cevaplar göz önünde tutulmuştur.

Kırgız isimlerinin ses-anlam çözümlemeleri için daha önce de belirtildiği üzere Clauson Etimolojik Sözlüğü ile Türk Dil Kurumu; Kişi Adları, Derleme ve Kırgıı Sözlüklerine ve Türkçenin Grameri (Banguoğlu, 1974) ile Pamir Ağzı üzerine yapılmış bir tez çalışmasının sözlük kısmına (Pekacar, 1995) başvurulmuştur. Bununla birlikte kılavuz kimselerin bilgilerinden de faydalanılmıştır. Mesela Pista/Pistan/ “pisik, kedi” karşılığını Derleme Sözlüğü’nde bulurken, Pista kişi adının "çekirdek” karşılığı kılavuz kimseden edinilmiştir.

Örneklem grubunun Ön Adları ve Bu Adların Olası Konulma Sebepleriyle Ilgili Verilmiş Cevaplarla İlişkili Olarak

\section{Dinî Adlar}

Örneklem grubunun adın konuluş sebebi sorusuna verdikleri dinî ad karşılığının yüzdelik sırası, verilen cevaplar arasında dördüncü büyük dilimi oluşturmaktadır. Üçüncü yüzdeliği karşılayan aile büyükleri adlarının ataya hürme- 
ten kullanımı; bu adların bir kısmının aynı hassasiyetle dinî ad olarak konulduğu şeklinde bir ihtimali de düşündürmektedir.

Din kaynaklı adlar içinde, en çok kullanılan kişi adlarından biri olan $\mathrm{Mu}-$ hammed adının, Kırgız dilinin ses özelliklerine göre zaman içinde Momo, Mammat, Mamet, Mat, Met ve benzeri ses-şekil dönüşümü geçirmiş türevleri vardır.

\section{Hz. Allah'in Ad ve Sifatlart}

Abdiş "Kulcuk", Abdulkamçi "İsyankârları itaat ettirenin kulu", Abdurrahman, Adildabay “Adil-zengin”, Azizullah, Cabbar, Ezullah “Azizullah”, Hâkim/ Akim/Ekim, Halıkul/Halıkkul "Hâlık olan Allah'ın kulu"

Sonunda "berdi/verdi" sözü bulunan adlar, mutlak güç ya da yaratıcı olarak vasıflandırılan varlığı hedef almış teofor adlar kapsamında görüldüğünden Egemberdi “sahibim verdi”, Hüdayibergen, Kerimverdi gibi kişi adları da Allah'ın ad ve nitelikleriyle ilgilidir.

Hz. Peygamber ve Diğer Peygamberler, Ailesi ve Sahabelerle İlgili Adlar Ayşe, Bekir, Bilal, Canali, Danyal, Enas/ Enes, Hacer, Hatice, Gulamnebi "Nebi kölesi", İdris, İsmail, Hüseyin, İsabeg, Mehmet, Meryem, Muhammed, Musa, Resul, Seyit/Seyyit, Yusuf.

\section{Dinî Çağrışım Değeri Taşıyan Diğer Adlar}

Onomastik biliminde teofor adlar olarak da tanımlanan bu adlarda Tanrı ya da kutsal bilinen bir takım motifler kullanılır. Ayubbay "zengin Eyyüp", Cumataç, Cumat/Cumāt/Cemāt "cemaat, Topluluk", Egemberdi "sahibimverdi”, Akimkul/Ekimkul "sahibinkulu”, : Emanullah, Emenullah, Ėnèpiya "Hanafi”, Ėvegül "Havva Gül”, Eyetullah “Allah'ın ayeti”, Pata "Fatiha”, Satılmış, Satıvaldı, Satkın, Satunkul, Satuvvaldır, Sayit/ Said "kutlu, uğurlu”, Sena, Tobokel "tevekkül”.

\section{Millî-Tarihî-Ananevî-Siyasî Adlar}

Kırgız Türkleri arasında yiğitliği nam salmış birinin özel ad olarak verilmesi öteden beri devam eden ad koyma alışkanlıklarındandır. Bu şekilde bebeğin taşıdığı ismin hatırasına layık bir ömür süreceği farz edilir.

Afsercan/Efsercan "subay”, Alparslan, Alperen, Bardıbek, Bibiturhan "saygın hanım”, Cengiz, Cutankı "aç, bîtap", Evren, İlhan "Moğol hükümdarlarının unvanı”, Kenan Evren, Manas, Semetay "Manas kahramanlarından" 


\section{Bedenle İlgili Adlar}

Abaş/ Abraş "çilli, sarışın, açık renk gözlü", Apal "İri, büyük”, Beşbibi "Beş: Hayvanların alınlardaki aklık: Alnı Ak Hanım", Cıpar/ Çipar "sarışın mavi veya yeşil gözlü; çilli”, Curus/Curuz "ufak tefek", Çüprö (<çürpö metatez ile< çöbürö) "ufak tefek"

\section{Meslekle Ilgili Adlar}

Toycu, Topcubay/Topcuvay

\section{Dış Çevreyle İlgili Adlar}

Günümüzde İslam dini tesirine rağmen bu tür kişi adlarının Ulupamir Kırgız halkı arasında kalıntı şeklindeki devamı, ailedeki saygın kimse ya da aile büyükleri adlarının bebeğe verilmesi alışkanlığı ile açıklanabilir.

Dış çevreyle ilgili adlar arasında doğum yerinin yakınında bulunan nehir, şehir, yayla, bina gibi çeşitli mekânların kişi adı olarak konulması yaygın bir kullanımdır. Aras, Kırgız, Pamir, Semerkant, Uygur gibi isimler hem çocuğun kimliğini belirginleştirmekte hem de sahip oldukları çağrışımlarıyla toplum hayat ve hatıratında önemli olan yer ve kavim adların toplum bilincinde diri tutmaktadır.

\section{Bitki Adlart}

Dış çevreyle ilişkilendirilecek ad gruplarındandır. Rastlanılan örneklerden bazıları: Cunus/ Cunuz "çimenlik”, Çınıgül "gerçek sağlam gül; cıñı 'gözyaşı' gül”, Çüçül "filiz, körpe, tomurcuk”, Gül, Gülasel "gül özü, gül balı”, Gülbibi, Gülnur, Kosok "kosek, koza, pamuk kozası”, Lale, Meñdigül "bir çeşit ot / Mañdugul/", Marcan, Pahta "pamuk", Peren "gri yeşil renkte bir tür bozkır bitkisi", Pista "çekirdek

\section{Su İle İlgili Adlar}

Dış çevreyle ilişkilendirilecek ad gruplarından sayılabilir, örnekler: Aras "nehir adı", Bogen/Bögen "kabaran nehir suyu"

\section{Hayvan Adları ve Hayvan Özellikleriyle İlgili Adlar}

Dış çevreyle ilgili kabul edilebilir, başlıcaları: Agulak "ak oğlak", Aycüce / cücü "kuş yavrusu", Böcök/Böcük "bıldırcın", Camiş/Camış/Camız "manda", Ceyren/Ceren "karaca”, Çöçö "civciv", Çüçül "küçük kuş, serçe”, Ergeş / Ergeç “teke”, Kaldıgaç "kırlangıç”, Kırg̀ol "sülün”, Koçkor “damızlık koç”, Kozu "kuzu, bala”, Pista/ Pistan/ Pisik "kedi”, Sono/Sona "yeşil başlı ördek” 


\section{Nesne Adlart}

Dış çevre adlarındandır. Başlıcaları: Afsercan/ Efsercan "taç", Çınıhan "çını 'porselenden mamul' piyale", Çöçül "sögüt ağacının kabuğundan yapılmış", Enel "bilye", Totiya (<(Ar.) tūtyā) "sürme, düzgün", Yakutbibi, Zeyne "zeyn+ e: süs, bezek", Züveyde/Zübeyde "cevher"

\section{Renk Adları}

Dış çevre adlarındandır. Başlıcaları: Renklerle ilgili adlar, dış görünümde göze değen çarpıcı özelliklerle de ilişkili adlardan sayılabilir.

Aksalkım, Altınçeç "sarı petek", Bos < Boz "açık toprak rengi” Gülal "kırmızı gül”, Gülpembe, Gülbeyaz, Karaçaç “siyah saç”.

\section{Tabiat Olaylart}

Dış çevre adları grubuna dâhil edilebilir. Başlıcaları: Bogen "kabaran nehir ya da ırmak suyu", Buğalça "yağmurdan sonra topraktan çıkan buğu, buğu parçası", Burul "şakırdayan, gürleyen su", Bürül "sabah ya da akşam vaktinin alaca karanlığı", Çilen "çisenti şeklinde yağan yağmur"

\section{Yeryüzü Şekilleri ve Mekân İle İlgili Adlar}

Dış çevre adları grubuna dâhil edilebilir. Başlıcaları: Adır "bozkır", Tille "dağ ya da ağaç tepesi”, Töbek, Turat "Tepecik”.

\section{Gök Cisim Adları}

Göğün kutsallığı Türk destanlarında sıkça rastlanılan bir olgudur. Dış çevre adları grubuna dâhil edilebilir. Başlıcaları: Apta "güneş", Aybike/Aybüke "Ay Hanım”, Altınay, Aycüce / cücü “tomurcuk, yeni ay”, Aysulu "güzel ay”, Ayyüce, Carkınay "parlak ay”, Çalpan/Çolpan/Çolpon/Çulpan "Venüs”, Gümüşay, Hatun Atlas "Gök Hanım”, Mihri "güneşe ait”, Şanay /Şanoy "şanı ay kadar yüksek

\section{Vakit-Sayı Motifli Adlar}

Bebeğin dünyaya geldiği vakti, günü anlatan zaman ile ilgili ifadeler veya ailede kaçıncı çocuk olduğunu anlatan sayı ibaresi, ad vermede etken olan motiflerdendir. Aşır/ Aşir "öğleden sonra", Altımış "Altmış 'yaş", Aytbibi "Bayram Hanım”, Başam "bu akşam”, Beşbibi, Bugül/Büğül "bu yıl”, Tunay “ilk; ilk çocuk", Zulgade/Zülhade "Kamerî ayların onbirincisi" 


\section{Farklı Duygu Değgerleri Taşıyan Soyut-Somut Adlar}

$\mathrm{Bu}$ gruptakiler dilek ve temenni ifadeli olanların yanı sıra güçlülük, saygınlık gibi beklentilerin de karşılığı sayılabilecek anlamları yüklenmişlerdir.

Okşama, Güzellik, İyilik, Kıymet, Mutluluk Benzeri Dilek ve Temenni

\section{Çă̆rışımı Taşıyan Adlar}

Kadın adları duygu merkezli düşünüldüğünden çoğunlukla bu gruptadır. (Rásony1 L., 1963: 85)

Bibisara "mümtaz, seçme hanım”, Bibigayrime, "Gayrim, gayrım, kayrım, kayrim: hayırsever, kayrımı çok, acıyı kederi paylaşan hanım”, Bibisure "İpekli Hanım"; şenlikli Hanım”, Bilge, Böcön/Böcün "saklanmış”, Burma "bürme, kıvrım, ince endam”, Burul "bürül, incel, endamlı ol”, Büdü "telaş, helecan”, Cakan “/şak-/ yanan, alevli”, Canan, Cavidan, Carkın(ay)

Temenni anlamı daha baskın olan adlar aşağıda sıralandığı gibidir:

Atimbibi / Hatimbibi, Törümkeldi “düzenim geldi”, Turatbeg “sabit kadem bey”, Tülen “usta, mahir”, Söykü/Söyke “destek”, Tunuk; Tonuk “temiz; durgun, sakin” Tursun, Üpel “mücevherli, en iyi kısım”, Zupunbibi “çağdaş, çağa uyan hanım”, Yaren

\section{Kuvvet, Üstünlük Çağrışımı Taşıyan Adlar}

Bagan “endamlı, güçlü yiğit”, Bibisure "mağrur bakışla bakan hanım”, Ceniş /Ceñiş/ Ceñişbek “yeniş, zafer”, Çeçe “efe”, Doktobibi “salim efendi”, Ece “abla”, Egeşbey “iddiacı”, Genceke/Gencege “yaşı küçük sözü büyük”, İlaşvek “ilaç beg”, Kamçıbeg “asileri itaat ettiren yiğit”, Ulka/Uluka "ululanma”

Sonu Han ile biten adlar da taşıdıkları duygu değeri açısından üstünlük algısıyla düşünülebilir. Nitekim Nogay Türklerinde Kişi Adlarıyla ilgili bir incelemede, sonu "Han" ile biten kadın adları Görkemli Adlar kategorisinde yorumlanmıştır. (Ergönenç, 2012: 112) Asılhan, Aslıhan, Ayimhan, Bazarhan, Neslihan, Sacehan, Ziyadehan gibi kadın Kırgız adları yanında Cengizhan, Kocahan, Kulayhan, Turnahan gibi erkek Kırgız adlarını da bu grupta dile getirilebilir.

\section{Mensubiyet Bildiren Adlar}

Arapbay, Arapbedir, Arapeke, Çı̆̆ıtıy, Kırgızhan, Nayman, Oğuz, Uygur 


\section{Kadın Grubu Kişi Adı Listesindeki Ses Yitimi ve Değişimine Ŭgrayan}

\section{Adlardan Örnekler}

Çalışmada kişi adları, mümkün olduğunca nüfusta geçtiği şekil ile ele alındığından adlandırma listelerinden verilecek örnekler sınırlı sayı iledir. Bazı kişi adlarındaki yuvarlaklaşma, dudak ünsüzü etkisine ilaveten ses düşmesi sonrası oluşan büzülme kaynaklı ikincil/dolaylı (Buran, 2006: 1) ses uzunlukları ile gerçekleşir: "Acuü < Hacuü < Hacovü < Hacabibi / Hacıbibi "Hacı hanım”; Taşuü < Taşvuü < Taşbü < Taşbi < Taşbibi “Taş hanım” örneğindeki gibi. Ses değişmeleriyle dikkat çeken diğer örneklerden bazıları:

Agulak “Ak Oğlak”, Atimbibi/Etimbibi/Hatimbibi "Seçilmiş hanım”, Bakıt/Bak < Baht, Başam "Bu akşam”, Bugül/Büğül "Bu yıl”, Bogön/Bogon/ boon "Bugün”, Ėvegül /Havva Gül, Genceke/Gencege, Iġbol/İkbal "baht”, Irayile, İriskul-İrisgul, Ivadathan/İbadethan, Karaçoç-Karaçaç "Kara saç”, Meñdigül (Mañdugul), Mervet/ Merbet (Farsça "İnci, Morvarid”), Miman / Miyman (Farsça Mihman), Urkiye (Göçüşme ile: Rukiye), Şarapat (Arapça Şerafet), Zımırat (Arapça Zumurrud)

\section{Erkek Grubu Kişi Adı Listesindeki Ses Yitimi ve Değişimine Ŭgrayan Adlardan Örnekler}

Abdullah $<$ Abdilla, Cemāt/Comat/Comāt, Çıgıtıy/Çı̆̆ıtıy $<$ Çagatay, Hursan/Hursen/Kursant "Hursend-Sevinen", Golomaydar < Gulam Haydar, Kavul < Kābil, Alakber, Golomaydar $<$ Gulam Haydar, Kurvan $<$ Kurban, Mammat, Mat, Met $<$ Muhammed, Mademin < Muhammed Emin (Kırg1z, 2009), Momoturdu $<$ Muhamed Durdu, Nazermamat, Nozmidin $<$ Nizameddin, Nurmammat $<$ Nur Muhammed, Orozvay/ Orozbay, Satuvvald $1<$ Satıp Aldı" , Seyfidin/Soypidin $<$ Seyfettin, Şagmardan $<$ Şahmerdan, Tohto /Tokto $<$ Tokta

(Sonradan Değiştirildiği Bildirilen Erkek Kişi Adı)

Aile bireyleri arasında "Sartbiy" denildiği hâlde nüfus kayıtlarında "Sertan" şeklinde geçtiği belirtilmiştir.

\section{Kadın ve Erkek Adlarında Ortak Olan Kişi Adlarından Örnekler}

Durdu, Turdu, Satıvaldı, Satılmış gibi temenni çağrışım değerindeki adlardır. 


\section{Ulupamir Kırgız Kadın-Erkek Kişi Adlarında Karşılaşılan Genel Ses}

\section{Değişimi Temayülleri}

Günümüz Kırgız dili ağızlarıyla ilgili kabul edilen yaygın görüşlerden biri Kuzey, Güneydoğu ve Güneybatı şeklindeki üç ağız grubunun olduğu yönündeki tezdir. (Yunusaliyev 1971) Pamir Kirgızları ve onlara mensup bir kol olan Ulupamir Kırgızları Ulupamir Mahallesinde konuşulan dil Kırgızcanın bir güneybatı ağzı olan İçkilik ağzıdır. (Kayıpov 2010: 181-199) Kırgız Türkçesinin standart ağzının bütün ses ya da şekil özelliklerini taşıma açısından diğer güneybatı ağızlarında olduğu gibi bir takım farklılıkları bünyesinde barındırır. Bu farklılaşımın başlıcaları, daha çok alıntılarda açık /e/ (è) ünlüsünün ortaya çıkışı, /ov/, /öv/, /uv/, /üv/ hecelerindeki ünlülerin kaymasıyla karşılaşılan diftong ve sonrasında, ikincil uzunlukların oluşumu şeklindedir. (Kırgız, 2009: 2)

Düzlük Yuvarlaklık uyumu Ulupamir Kırgız dilinde düz ünlüden sonra düz, yuvarlak ünlüden sonra yuvarlak olacak şekildedir. (İnan,1965: 67-76) Kırgız Türkçesi bu baskın yuvarlaklaşma temayülü yönüyle Altay ve Tuva Türkçeleriyle benzerlik ihtiva eder. Karşılaşılan örneklerdeki bu ses olayı genelde ünlü benzeşmesiyle oluşmuş ve dudak ünsüzlerinin tesiriyle gelişmiştir. Türkçe adlarda ya da alıntı adlandırmalarda ilk hecede bulunan "o" ünlüsü, kendisinden sonra gelen hecelerdeki /a/ sesini yuvarlaklaştırmıştır "Coldoş < Yoldaş" gibi. Alıntılarda ses düşmesi sonrası ikizleşen ünlüler, kelimelerin söylenişinde uzun ünlü ezgisi oluşturur.

Alıntı olan Muhammed sözündeki yuvarlaklaşma tarzındaki ses olayı, Momun örneğindeki gibi kelime başında ve ortasında bulunan “ $m$ ” ünsüzü etkisiyledir. Ama Ulupamir Kırgız Türkçesinin, yuvarlaklaşmayı diğer Türk dillerine kıyasla ileri seviyelere taşıması karekteristiktir.

\section{Yalın Kişi Adlarındaki Ses Deģ̆̈şimleriyle İlgili Başlıca Özellikler}

1. Yalın kişi adlarında kalınlık incelik uyumu bulunmaktadır Çı̇̇ııı, Begen gibi.

2. Düzlük yuvarlaklık uyumu düz ünlülerden sonra düz Alma, Aydın, Begen; yuvarlak ünlülerden sonra yuvarlak Yumuş, Cumuş, Yoldoş gibi; yalnız dar yuvarlak ünlülerden sonra /a/ ünlüsü gelir Turat, Ulka, Turgan gibi

3. Bögen- / Bögün- < Begen- düz geniş ünlü yuvarlaklaşmasının sık olması Kırgız dilindeki hâkim yuvarlaklaşma temayülü sebebiyledir. 
4. Ėvegül $<$ Havva Gül, Eyet $<$ Ayet, Bèzipè $<$ Bazıpa ( $<$ Vazīfe) gibi alınt1 adlarda bazen kalın ünlülerin incelmesi durumu yaşanmaktadır. Türkçe adlarda da ayn incelme olabilmektedir Siype $<$ Siypa.

5. Camış < Cemiş "Yemiş" olduğu gibi bazen ince ünlü şekillerin kalınlaştığı da olur. Bu durum alıntalarda da vardır: Mammat, Zura (Mehmet $<$ Muhammed; Zühre).

6. Cürök < Yürek olduğu gibi düz geniş ünlülerin yuvarlaklaşma eğilimi vardır.

7. Kelime başındaki /y" ünsüzü sadalı ses /c/ye dönüşür. Cemiş < Yemiş; Ceñiş $<$ Yeñiş; Cumuş $<$ Yumuş

8. Aybattu < Haybat; Acuü < Hacuvü gibi bazı alıntılarda adlarda kelime başındaki /h/ sesinin düştüğü görülür.

9. Aynı adın ilk hecede yuvarlak-geniş "Torgoy, Kodaş" ile yuvarlak-dar “Turgay, Hudaş” ve ikinci hecede düz-geniş ünlü hâlleri "Torgay” vardır.

10. Coven, Tayir örneklerindeki gibi alıntı adlarda ses değişimi yaşansa da ünlü uyumuna rastlanmayabilir.

11. Genel olarak ünlü uyumları adlara hâkimdir. Ig̉bol < İkbal örneğinde olduğu gibi zaten kalınlık incelik uyumunun bulunmadığı alıntı adlarda uyum, bir anlamda bu şekilde işletilmiş olabilmektedir.

12. Ünsüz uyumu adlarda hākim bir unsurdur. Yalnız Dokto $<$ Tokto örneğinde olduğu gibi bazen sert ünsüz ses kelime başında sadalı hâle dönüşebilir.

13. Tohto < Taḳto örneğindeki gibi kelime ortasındaki arka damak sesleri birbiri yerine dönüşebilmektedir. Bu dönüşüm esnasında bazen ilk hecedeki geniş düz ünlü yuvarlaklaşır.

Baḳıt/Baḳ < Baḩt örneğinde olduğu gibi $\mathbf{k}<$ h h şeklindeki ses değişimi alıntılarda da görülmektedir.

14. Hudaş < Kodaş örneğindeki gibi kelime başındaki arka damak sesleri de birbiri yerine dönüşebilmektedir. Bu dönüşüm esnasında bazen ilk hecedeki geniş yuvarlak ünlü darlaşır. 
15. Kavul < Kābol "Kābil"; Taşvü < Taşbü örneklerinde olduğu gibi yuvarlaklaşmanın hâkim olmasının sonucu dudak sesi, b-f arası boğumlanan diş dudak /v/ sesine dönüşmektedir.

16. Vay < Bay dudak ünsüzü /b/ sesinin, kendisine yakın yerde boğumlanan diş dudak sesi /v/ye dönüştüğü örnekler vardır.

Bèzipè, Bazıpa $<$ Vazīfe örneğindeki gibi /b $<$ v/ ses dönüşümleri de vardır ama nadirdir.

17. Boy < Bay örneğindeki gibi, dudak ünsüzü /b/ sesi yanındaki düz-geniş ünlüyü, yuvarlak-geniş ünlüye çevirmiştir.

18. Geldibek örneğinde olduğu gibi kelime baş1/k/ sesinin /g/ye dönüşmüş hâli nadir de olsa vardır. Ama adın başındaki $/ \mathrm{k} /$ sesinin korunduğu örnekler daha çok vardır "Keldibek, Kiçikbü, Köçikbü, Kümüş".

19. $\mathrm{Büu/} \mathrm{Bi}<\mathrm{Bey}<\mathrm{Beg}<\mathrm{Bek}$ örneğinde olduğu gibi kelime sonundaki $/ \mathrm{k} /$ nin korunduğu örneklerle beraber sesin değiştiği hatta ses kayması yaşandığ 1 örnekler vardır.

20. Büu/ Bi < Bey örneğinde olduğu gibi sesin kaydığı ya da düştüğü durumlarda kelimelerde ikincil uzun ünlü durumu yaşanmaktadır.

21. Acuü $<$ Hacuvü $<$ Hacubü $<$ Hacubi $<$ Hacabibi; Taşüu $<$ Taşvü $<$ Taşbü $<$ Taşbibi, Turduü $<$ Turduvü örneklerindeki gibi diş dudak sesi düşüp yerini uzun ünlüye bırakır.

22. Kelime başındaki Türkiye Türkçesine göre arkaik kabul edilen /t/ sessizi bazı kişi adlarında korunmaktadır. Taşbibi, Turganbibi.

23. Sėyfel $<$ Sėypel $(<$ Stypa-l); Sedep $<$ Sedef; Bėzipe $<$ Vazīfe örneklerinde olduğu gibi diş dudak sesi /f/nin, dudak sesi /p/ye dönüşmesi söz konusudur. Bu dönüşüm alıntı adlarda ünlü yuvarlaklaşmasıyla beraber gerçekleşir: Sapure $<$ Sapire $<$ Safura ; yuvarlaklaşma olmadan gerçekleşen dönüşümler de vardır Pettah, Peyiz gibi

24. Moncok ve Muncuk örneğinde olduğunda gibi kelime başındaki dudak sesi /b/, hece içinde $/ \mathrm{n} /$ ünsüzü varsa $/ \mathrm{m}<\mathrm{b} /$ değişimi gerçekleşir.

25. Mosture "Mestūre" örneğinde olduğu gibi bilhassa alıntılarda kelime başındaki /m/ dudak sessizi yanındaki sesliyi yuvarlaklaştırır. 
26. ḳıs < ḳız, ġz "kız" kelimelerinde olduğu gibi Kırgız dilinde $\mathrm{s}<\mathrm{z}$ dönüşümü bilhassa sert ünsüzlerin ardından benzeşme sonucu gerçekleşir. (Kılıç, 2003: 96) "bis < biz; bos < boz" gibi yumuşak ünsüzlerden sonra da görülmesi mümkündür. "Cunuz $<$ Cunuz; Curus $<$ Curuz" kelimeleri de bu tür ses değişimine örnek olabilir.

27. Ulumbeg: ūulum < og̉ulum örneğinde iyelik eki öncesi diftongla beraber ses kaynaşması gerçekleşmiştir.

\section{Kelime ve Eklerin Birleşimindeki Başlıca Ses Özellikleri}

1. Bāşam "Bu akşam”, Būgül/Büğül "Bu yll”, Bógön/Bogon/boon "Bugün” örneklerinde olduğu gibi tamlama şeklindeki kişi adı birleşimlerinde düşen ses ardında, ikincil ünlü uzunlukları oluşturmuştur şeklinde düşünmek mümkündür. Demirci'nin bir ağız derlemesi çalışmasında "bual < bu gel: Bu sefer" şeklinde tespit ettiği karşılık bu bağlamda dikkat çekicidir (2017: 1369).

2. Vasita eki "ile" "menen"dir: Sārmenen.

3. Ulumbeg: ūlum < og̀ılum ses kaynaşmasının (Pekacar, 1995: 25) görüldüğü bu örnekte "I. tekil şahıs iyelik eki” kullanılarak kişi adı oluşturulmuştur.

4. Kuttu (kutlu), Aybattu (heybetli) kişi adlarındaki gibi kelime sonunda /+lU/ sıfat yapma eki, /ū/'ya dönüşmeden evvel sertleşmekte ve kelimenin son sesi ikizleşmektedir.

5. Toycu, Toyluk örneklerinde olduğu gibi daha çok uğraşı isimleri yapan /+CI/ ve sıfat yapan /+lUk/ yapım ekiyle gerçekleşmiş kişi adları vardır

6. Törümkeldi örneğindeki gibi görülen geçmiş zamanın kullanıldığı kişi adları vardır.

7. Bergen, Kaldlk, Satkın, Turgan örneklerindeki gibi sıfat fiil eklerinin kullanıldığı kişi adları vardır.

8. Çapar örneğinde olduğu gibi geniş zaman ekiyle gerçekleşmiş kişi adları vardır.

9. Satıvald $<<$ Satıp aldı örneğinde olduğu gibi /p/ zarf fiil eki kendisinden sonra ünlü gelirse yumuşamakta /v/'ye dönmekte. Bu şekilde gerçekleşmiş birleşik fiil tarzında kişi adları vardır 
10. Hāldār örneğinde olduğu gibi bay, bek, beg, bibi, han gibi Türkçe köklü kelimelerle birleşik ad yapılmaktadır. Bunun yanı sıra Farsça /+dār/ eki ya da Arapça Molla, Hacı gibi kelimeler kullanılarak da birleşik yapıdaki kişi adları oluşturulmaktadır.

\section{Tartışma ve Sonuç}

Örneklem grubunun önemli bir kısmını öğrenciler ve ev hanımları oluşturmaktadır. Mahallenin \%42,3’ü üç kuşaktır aynı köyde oturan sakinlerdendir. Grubun \%44,2'si 1000tl'lik bir geçim standartına sahiptir. Bu grubun \%47'lik pay ile yarıya yakın kısmı Ulupamir'de doğan kimselerden oluşmaktadır. Ulupamir'e göç ettiğini belirten \%55'lik dilime, ne zaman göç edildiği sorulmuş ve bunların \%67'sinin 1982'de bu göçü gerçekleştirdiği anlaşılmıştır.

Ulupamir Kırgız Türklerinin ad verme alışkanlıkları ve ad vermede önem arz eden etmenler, dönem ve coğrafya değişmiş olsa da Türk dil ve kültürünün hüküm sürdüğü uluslar için geçerli sayılan yaygın temayüller ile benzer bir seyirdedir. Bu benzerliklerin yanı sıra kişi adlarındaki yuvarlaklaşma, ikincil yapıdaki uzun ünlüler, ses düşmesine bağlı ünlü ikizleşmeleri ya da yanyana ünsüz seslerin yinelenmesi, Anadolu Türkçesine göre arkaik kabul edilen aslî seslerin hâlâ korunuyor oluşu gibi özellikler, bağlı olunan dil yapısından tam kopuşun henüz tamamlanmadığının işaretleridir.

Yetişen genç nesil, geleneksel aidiyet bilincine referans veren bir yönelim içinde olsa da gerek yaşanılan Anadolu kültürünün zihniyet etkisi gerek küresel dünyadaki moda eğilimlerin yarattığı şuur altı yansımaları, sosyal dinamiklerin her çeşitinde olduğu gibi ad verme sisteminde de geleneksel dokuyu bozabilmektedir. Mesela adı Sartbiy Efe olan kişinin, daha sonra kendi arzusuyla Sertan şeklindeki ad değişikliğini mahkeme kararıyla gerçekleştirmesi bahsedilen unsurların bir etkisidir. Zira Sertan adının, bölgede yaşayan Kürt ahali arasında revaç gören bir kişi adı olduğu, kılavuz kimse tarafından dile getirilmiştir. Nitekim geleneksel yönelimler ile modern eğilimler kimi vakit çatışabilmekte ve bugünün bakışı baskın olabilmektedir. Bu durumun bir iki örnekte tespiti yani alt düzeyde olması toplumsal farklılaşmanın sınırlı çerçevede kaldığını gösterir. Buna rağmen değişim geleneksellik aleyhine yavaş ama sürekli ilerlemektedir. 
Kişi adları anlam açısından değerlendirildiğinde, kadın adları duygu merkezli düşünülmüş olduğundan çoğunlukla güzel, hoş anlamlı ve iyi dilek ifadeli 'hypochoristica' grubundan olan adlardır. (Rásonyı, 1963: 85) Erkek adlarında baskın olan güzellikten ziyade uz, güç ve kudretten yana olan adlandırmalardır. Sonu Han ile biten adlar da taşıdıkları duygu değeri açısından güç ve kudret algısıyla uyumlu düşünülebilir. Erkek kişi adı grubu içinde bulunan bazı adların yapı açısından emir çekimiyle ya da mastar ekiyle yapılmış olması ayrıca dikkat çekicidir. Hasal, Hoşöl, Hoşbarmak "bar-: var-" gibi.

Kişi adlarının, tabiat, inanç, sosyal ve fiziki çevre, insanî ve toplumsal ilişkiler ağı gibi birbirinden farklı unsurlarla kurulu bağları olduğu muhakkaktır. Bahsi geçen bu bağlar münasebetiyle farklı disiplinlere malzeme çeşitliliği sunulmak istenen bu incelemede, Ulupamir Kırgız kişi adlarıyla ilgili seçimler günümüze ait temayüllerle yansıtılmaya çalışılırken dile özgü anlamsal çözümleme denemeleri verilmeye çalışılmıştır. Bu şekilde Türk onomastiğinin değerlendirilmesine yerel çapta da olsa bir fayda gerçekleştirme hedeflenmiştir. 


\section{Kaynakça}

Acıpayaml1, Orhan (1992). "Türk kültüründe Ad Koyma Folkloru'nun Morfolojik Ve Fonksiyonel Yönlerden İncelenmesi” IV. Milletlerarası Halk Kültürü Kongresi Bildirileri, Gelenek, Görenek ve İnançlar IV/ 1-15

Ergönenç, A. D. (2012). "Nogay Türklerinde Kişi Adları”, Dil Araştırmaları, Sayı.10; sayfa 99-122.

Aksan, D. (1977, 1982). Her Yönüyle Dil 1,3, Ankara: Türk Dil Kurumu Yayınları.

_ (1987). Her Yönüyle Dil. Cilt I., Ankara: Atatürk Kültür ve Tarih Yüksek Kurumu.

— (1995). Her Yönüyle Dil/Ana Çizgileriyle Dilbilim, Ankara: Türk Dil Kurumu Yayınları.

Ayverdi, İ. (2005). Misalli Büyük Türkçe Sözlük, İstanbul: Kubbealtı Neşriyat.

Banguoğlu, T. (1974). Türkçenin Grameri, İstanbul: Baha Matbaası.

Buran, A. (2006). "Çağdaş Türk Yazı Dillerinde Ve Türkiye Türkçesi Ağızlarında İkincil Uzun Ünlüler”, (10-12 Nisan) II. Kayseri Ve Yöresi Kültür, Sanat Ve Edebiyat Bilgi Şöleni, Erciyes Üniversitesi Kayseri.

Clauson, G. (1972). An Etymological Dictionary of pre-thirteenth-century Turkish, Oxford At The Clarendon Press.

Çelik, C. (2005). Ísim Kültürü Ve Din. Konya: Çizgi Kitabevi.

Demirci, M. (2017). “Derleme Sözlüğü’ne Osmaniye, Düziçi Ağzından Katkılar” Teke Uluslararası Türkçe Edebiyat Kültür Eğitim Dergisi. Sayı. 6(3), ss.1360-383.

Dilipak, A. vd. (1996). Ansiklopedik İsim Sözlüğ̈̈ İstanbul: Risale Yayınları.

Erciş Nüfusu. http://www.nufusune.com/ercis-ilce-nufusu-van (e.t. 15.06.2017)

Ergin, M. (2000). Türk Dil Bilgisi, İstanbul: Bayrak Yayınları.

Gülensoy, T. (1999). “Türk Kişi Adlarının Dil Ve Tarih Açısından Önemi”, Türk Dil Ve Edebiyat Dergisi (Türk Dili) C: 1999/I, Sayı: 565; Sayfa.3-8.

İnan, A. (1965). “Kazak Ve Kırgız Yazı Dillerinde Dudak Benzeşmesi (Labial Attraksiyon) Meselesi”, Türk Dili Araştırmaları Yıllığı Belleten, 1964, Sayfa. 67-76 Ankara

Kalın, İ. (2016). Ben, Öteki Ve Ötesi (İslam-Batı İlişkileri Tarihine Giriş), İstanbul: İnsan Yayınları. S. 331, 4. Bask1.

Kayipov, S. (2010). "Ethnological Review Of The Van Kyrgyz”, International Journal Of Central Asian Studies, 2010/14 Seoul, Korea, S. 181-199.

Kılıç, F. (2003). "Kırgız Türkçesinin İçkilik Ağzı”, Kök Sosyal Ve Stratejik Dergisi, Vol. V., Num, 1. (Spring) S. 81-135

Kırgız, Ayşe Nur (2009). Van Ulupamir Kırgız Ağzı Üzerine Derleme Çalışması (İnceleme- 
Metin-Sözlük) Yüksek Lisans Tezi, İstanbul Marmara Üniversitesi Türkiyat Araştırmaları Enstitüsü.

Kişi Adları Sözlüğü. http://www.tdk.gov.tr (e.t. 14.08.2017)

Kişi Adları. http://tdk.gov.tr/index.php?option=com_kisiadlari\&view=kisiadlari (e.t. 11.07.2017)

Kubbealt1 Lugat1. http://lugatim.com (e.t. 10.09.2017)

Ögel, B. (2003). Türk Mitolojisi I, Ankara: Türk Tarih Kurumu Yayınları, Sayfa: 498-511.

Pekaçar, Ç. (1995). Pamir (Afganistan) Kırgız Türkleri Ağzı, Doktora Tezi, Ankara: Gazi Üniversitesi, Sosyal Bilimler Enstitüsü.

Rásonyi, L. (1963). “Türklükte Kadın Adları”, Türk Dili Araştırmaları Yıllı̆̆ı Belleten, Sayfa 63-87, Ankara.

Sakaoğlu, S. (2001). Türk Ad Bilimi I: Giris, Ankara: Türk Dil Kurumu Yayınları, S. 9-10-11.

Türkiye İstatistik Kurumu http://tuik.gov.tr/PreIstatistikTablo.do?istab_id=1332 (e.t.

07.07.2017)

Ülkütaşır, M. Ş. (1938). Türklerde Ad Verme Âdetleri, Halk Bilgisi Haberleri 81, 194-199.

Yıldız, N. (1994). Manas Destanı (W. Radloff) Ve Kırgız Kültürü İle Illgili Tespit Ve Tahliller, Doktora Tezi, Ankara: Gazi Üniversitesi Sosyal Bilimler Enstitüsü.

Yudahin, K. K. (1998): Kırgız Sözlüğ̈̈ (S.S.C. B. Bilimler Akademisinin Doğuyu İnceleme Enstitüsü, Abdullah Taymas (Çev.), Ankara: Atatürk Kültür, Dil Ve Tarih Yüksek Kurumu Türk Dil Kurumu Yayınları: 93-121, Cilt:1-Cilt: 2.

Yunusaliyev B. M. (1971). Kırgız Dialektologiyası, Frunze, Mektep Basması. 